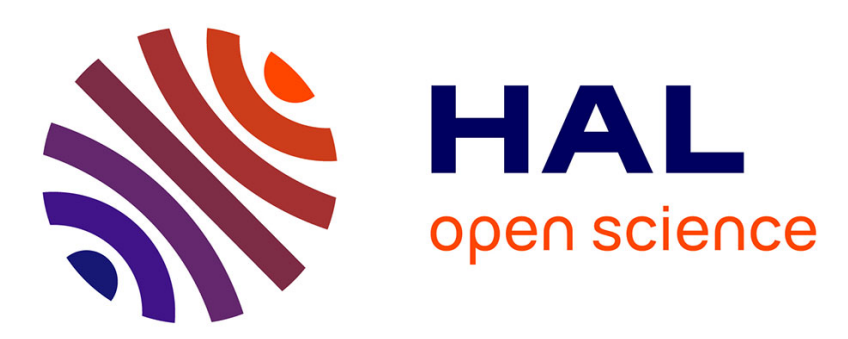

\title{
Functional fluoropolymers for fuel cell membranes
}

\author{
R. Souzy, Bruno Ameduri
}

\section{To cite this version:}

R. Souzy, Bruno Ameduri. Functional fluoropolymers for fuel cell membranes. Progress in Polymer Science, 2005, 30, pp.644-687. 10.1016/j.progpolymsci.2005.03.004 . hal-00382623

\section{HAL Id: hal-00382623 \\ https://hal.science/hal-00382623}

Submitted on 9 May 2009

HAL is a multi-disciplinary open access archive for the deposit and dissemination of scientific research documents, whether they are published or not. The documents may come from teaching and research institutions in France or abroad, or from public or private research centers.
L'archive ouverte pluridisciplinaire HAL, est destinée au dépôt et à la diffusion de documents scientifiques de niveau recherche, publiés ou non, émanant des établissements d'enseignement et de recherche français ou étrangers, des laboratoires publics ou privés. 


\title{
Functional fluoropolymers for fuel cell membranes
}

R. Souzy ${ }^{1}$ and B. Améduri ${ }^{1}$ *

\author{
${ }^{1)}$ Laboratory of Macromolecular Chemistry, UMR (CNRS) 5076, Ecole Nationale Supérieure \\ de Chimie de Montpellier, 8 Rue Ecole Normale, 34296 MONTPELLIER Cedex 5 - France
}

*To whom correspondence should be sent. E-mail: ameduri@cit.enscm.fr.

\begin{abstract}
Various routes to synthesise functional fluoropolymers used in membranes for fuel cells applications are presented. They can separate into three main families of alternatives. The first one concerns the direct radical copolymerisation of fluoroalkenes with fluorinated functional monomers. These latters are either fluorinated vinyl ethers, $\alpha, \beta, \beta$-trifluorostyrenes or trifluorovinyl oxy aromatic monomers bearing sulfonic or phosphonic acids. The resulting membranes are well-known Nafion $^{\circledR}$, Flemion ${ }^{\circledR}$, Hyflon $^{\circledR}$, Dow ${ }^{\circledR}$, Aciplex ${ }^{\circledR}$ or BAM3G ${ }^{\circledR}$. The second way deals with the chemical modification of hydrogenated polymers (e.g. polyparaphenylenes) with fluorianted sulfonic acid synthons. The third possibility concerns the synthesis of FP-g-poly(M) graft copolymers (where FP and M stand for fluoropolymer and monomer, respectively) obtained by activation (by irradiation such as electrons, $\gamma$-rays, ozone or plasma) of FP polymer followed by grafting of $\mathrm{M}$ monomers. The most used $\mathrm{M}$ is styrene(s), and a sulfonation was achieved onto FP-g-PS leading to FP-g-PS sulfonic acid copolymers. The electrochemical properties (ionic exchange capacity, conductivity, swellingrate) of the membranes produced from of these fluoropolymers bearing sulfonic, carboxylic or phosphonic acid are supplied and discussed.
\end{abstract}




\section{$\underline{\text { Table of Contents }}$}

List of Symbols and Abbreviations

Conclusion

Acknowledgement

References

Figures

Schemes

Tables 


\section{List of Symbols and Abbreviations}

$\begin{array}{ll}\text { AIBN } & \text { azobisisobutyronitrile } \\ \text { CTFE } & \text { chlorotrifluoroethylene } \\ \text { DMF } & \text { dimethylformamide } \\ \text { DPn } & \text { average degree of polymerization in number } \\ \text { DSC } & \text { differential scanning calorimetry } \\ \text { HFIB } & \text { hexafluoroisobutylene } \\ \text { HFIP } & \text { hexafluoroisopropanol } \\ \text { HFP } & \text { hexafluoropropene } \\ \text { Mn } & \text { average molecular weight in number } \\ \text { Mw } & \text { average molecular weight in weight } \\ \text { PFCB } & \text { perfluorocyclobutane } \\ \text { PMVE } & \text { perfluoromethylvinyl ether } \\ \text { RT } & \text { room temperature } \\ \text { Tg } & \text { glass transition temperature } \\ \text { TFE } & \text { tetrafluoroethylene } \\ \text { TFS } & \text { trifluorostyrene } \\ \text { TGA } & \text { thermal gravimetric analysis } \\ \text { VDF } & \text { vinylidene fluoride } \\ \text { UV } & \text { ultra violet } \\ \end{array}$




\section{Introduction}

Aliphatic and aromatic fluorinated polymers exhibit a unique combination of high performance properties [Wall L A, Fluoropolymers. New York:Wiley Publisher, 1972] [Labadie J W, Hedrick J L. Perfluoroalkylene-activated poly(aryl ether) synthesis. Macromolecules 1990;23(26):5371-5373]/Yamabe M. A challenge to novel fluoropolymers. Makromol. Chem. Macromol. Symp. 1992;64: 11-18][Mercer F, Goodman T, Wojtowicz J, Duff D. Synthesis and characterization of fluorinated aryl ethers prepared from decafluorobiphenyl. J. Polym. Sci., Part A : Polym. Chem. 1992;30(8):1767-1770][A. E. Feiring, Fhuropolymers; In Organofluorine Chemistry Principles and Commercial Applications. New York: Banks R E, Smart B, Tatlow T C 1994;15:339][Feiring A E J. Synthesis of new fluoropolymers: tailoring macromolecular properties with fluorinated substituents. Macromol. Sci., Pure Appl. Chem. 1994;A31(11):1657-1673/Feiring A E J, Imalzano J F, Kerbow D L, Developments in commercial fluoroplastics. Trends Polym. Sci. 1994;2(1):26-30][Scheirs J, Modern Fluoropolymers. Victoria, Australia:Wiley Publisher, 1997][Hougham G, Johns K, Cassidy P E, Davidson T. Fluoropolymers: synthesis and polymerization. New York:Plenum Press, 1999][Ameduri B, Boutevin B, Kostov G. Fluoroelastomers: synthesis, properties and applications. Prog. Polym. Sci. 2001;26(1):105187/[Souzy R, Ameduri B, Boutevin B, Synthesis and (Co)polymerization of Monofluoro-, Difluoro-, Trifluoro-Styrene and [(Trifluorovinyl)oxy] Benzene. Prog. Polym. Sci. 2004;29(2):75-106][B. Ameduri, B. Boutevin, Well-Architectured Fluoropolymers, Synthesis, Properties and Applications, Elsevier, Amsterdam, 2004]. Despite their price, such product are involved in many high tech-applications (aerospace, aeronautics, optics, microelectronics, paints and coatings, engineering and biomaterials...) and especially in the preparation of ion exchange resins WW. G. Grot, C. J. Molnar, P. R. Resnick, AU 544027, assigned to DuPont de Nemours, 1985]/T.D. Gierke, W. Y. Hsu, in perfluorinated ionomer membranes, A. Eisenberg, H. L. Yeager (Eds), ACS Symposium Series, No 180, Ch 13, p 283 (1982)]/G. Pourcelly, C. Gavach, in "Proton Conductors, solids, Membranes, and Gels-Materials and devices",P. Colomban (Ed), Cambridge University Press, Cambridge (1992)] [C. HeitnerWirguin, J. Membr. Sci. 120, 1 (1996)]/W. G. Grot, Macromol. Symp., 82, 161 (1994)][R.E. Fernandez, "Perfluorinated ionomers", in "Polymer Data Handbook", Oxford University Press, Oxford, 233-236 (1999))/M. Dolyle, G. Rajendram, "Perfluorinated membranes",in Handbook of Fuel Cells - Fundamentals, Technology and Applications, edited by Wolf Vielstich, Hubert A. Gasteiger, Arnold Lamm., Vol. 3: Fuel Cell Technology and 
Applications. 2003, J. Wiley \& Sons][D. D. DesMarteau, C. W. Martin, L. A. Ford, Y. Xie, US Patent 6,268,532, assigned to 3M Innovative Properties company, 2001] and Proton Exchange Membrane for Fuel Cell (PEMFC) /C. W. Martin, P. J. Nandapurkar, S. S. Katti, in Polymeric Materials Encyclopedia; CRC Press Inc., Boca Raton, FL, 1995.]/C. Stone, A. E.

Steck, R. D. Lousenberg, US 5,602,185, assigned to Ballard Power Systems Inc., 1997]/C. Stone, T. S. Daynard, L. Q. Hu, C. Mah, A. E. Steck, J. New Mater. Electrochem. Syst. 2000, $3(1), 43-50]$.

The objectives of this chapter concern the synthesis and properties of fluoro-polymers involved in the elaboration of PEMFC. It is divided into three parts. After reporting a nonexhaustive list of hydrogenated polymers (mainly heterocyclic ones), the main parts are devoted to fluoropolymers achieved directly from radical copolymerization of aliphatic or aromatic fluoromonomers with fluoroalkenes and other comonomers. A complementary subchapter deals with chemical modifications of hydrogenated polymers with fluorinated synthons or concerns the synthesis of fluorinated grafted copolymers obtained by irradiation of fluoropolymers followed by grafting monomers.

\section{1-PEMFC based on non fluorinated polymers}

PEMFC membranes can be prepared from two categories of polymers [A. E. Steck, in proceedings of the "First International Symposium on New Materials for Fuel Cell Systems"; Eds. O. Savadogo, F. R. Roberte, T. N. Veziroglu, Montreal, Canada, July 9-13, 1995, 74][O. Savadogo, J. New Mat. Electrochem. Systems 1998, 1, 47-66] [Li, Q.; He, R.; Oluf.Jensen, J.; Bjerrum, N. J. Chem. Mater. 2003, 15, 4896-4915] [M. Dolyle, G. Rajendram, "Perfluorinated membranes", in Handbook of Fuel Cells - Fundamentals, Technology and Applications, edited by Wolf Vielstich, Hubert A. Gasteiger, Arnold Lamm., Vol. 3: Fuel Cell Technology and Applications. 2003, J. Wiley \& Sons].

The first categorie of aromatic polymers encompassed non-fluorinated macromolecules (Table 1) like sulfonated polystyrenes (crosslinked or not) /G. D'Alelio, US Patent 2,366,007, 1944] [J.M. Abrams, Ind. Eng. Chem. 1956, 48, 1469]/K. Prater, J. Power Sources 1990, 29, 239], sulfonated polyimides (PI) [S. Faure, R. Mercier, P. Aldebert, M. Pineri, B. Sillion, Fr Patent 9,605,707, 1996], sulfonated poly(aryl ether sulfones) [R. Nolte, K. Ledjeff, M. Bauer, R. Mulhaupt, J. Membrane Sci. 1993, 83, 211$]$ [R. Nolte, K. Ledjeff, M. Bauer, R. Mülhaupt, 
BHR Group Conf. Ser. Publ. 1993, 3, 381], sulfonated poly(aryl ether ketones) [F. HelmerMetzman, F. Osan, A. Schneller, H. Ritter, K. Ledjeff, R. Nolte, R. Thorwirth, European Patent 574,791,A2 1993], sulfonated phenol formol resins [B. Adams, E. Holmes, J. Soc. Chem. Ind. 1935, 54, 17], sulfonated poly(phenylene oxide) [A. S. Hay, U.S. Patent 3,432, 466 1969] [R. B. Hodgdon, A. S. Hay, US Patent 3,528,858 1970], Sulfonated Poly(pphenoxybenzoyl-1,4-phenylene) [Balland-Longeau, A.; Pereira, F.; Capron, P.; Mercier, R. Fr Patent 0,210,008 assigned to CEA 2002][Leninivin, C. PhD dissertation, Poitiers University, 2003], phosphonic poly(phenylene oxide) [I. Xiao, I. Cabasso, Polym. Mater. Sci. Eng. (Am. Chem. Soc., Div. PMSE) 1993, 68, 55-62], sulfonated silicates [J. Roziere, D. Jones, J. Anmu. Rev. Mater. Res. 2003, 33, 503-555], sulfonated poly(benzimidazole) [J. Roziere, D. Jones, J. Anmu. Rev. Mater. Res. 2003, 33, 503-555] and sulfonated organicinorganic hybrids II. Gautier-Luneau, A. Denoyelle, J. Y. Sanchez, C. Poinsignon, Electrochimica Acta. 1992, 37, 1615].

\section{Insert Table 1}

Nevertheless, most of these non-fluorinated ionomer membranes $\left(\$ 100 / \mathrm{m}^{2}\right.$ range) are characterized by a poor resistance to oxidation and thermal degradation.

\section{$\underline{\text { 2-PEMFC based on fluorinated copolymers }}$}

The second categorie of PEMFC can be obtained from fluorinated polymers. This section seeks to report the synthesis and the characterization of proton exchange membrane for fuel cell (PEMFC) based on aliphatic perfluorinated polymers. The second part covers the prepartion of PEMFC wikth aromatic copolymers.

\subsection{PEMFC based on aliphatic fluorinated polvmers}

\section{BRUNO incorpore ta partie ici.}

As reported previously, these materials can be synthesized by direct (co)polymerization of aliphatic perfluorovinyl monomers [Arcella, V.; Ghielmi, A.; Tommasi, G. Ann. N.Y. Acad. Sci. 2003, 984, 226-244][Doyle, M.; Rajendran, G. "Perfluorinated Membranes" in Handbook of Fuel Cells- Fundamentals, Technology and Applications, Vielstich, W.; 
Gasteiger, H.A.; Lamm, A. 2003, 3(30), 351-395][Li, Q.; He, R.; Oluf Jensen, J.; Bjerrum, N. J. Chem. Mater. 2003, 15, 4896-4915]/Ukihashi, H.; Yamabe M.; Mikaye, H. Progr. Polym. Sc. 1986, 12, 229-270][Ezzel, B. R.; Carl, W. P. EU Patent 289,869 assigned to Dow Chemical Co. 1988][Ezzel, B. R.; Carl W. P. US Patent 4,940,525 assigned to Dow Chemical Co. 1990][Babb, D. A.; Clement, K. S.; Ezzel, B. R. US 5,023,380 assigned to Dow Chemical

Co. 1991][Babb, D. A.; Clement, K. S.; Richey, W. F.; Ezzel, B. R. US 5,037,917 assigned to Dow Chemical Co. 1991][Babb, D. A.; Clement, K. S.; Ezzel, B. R.. (Dow Chemical). US 5159038, 1992][Kostov, G.; Kotov, S.; Ivanov, G.D.; Todorova, D. J. Appl. Polym. Sc. 1993, 47, 735-741][Xu, X.; Cabasso, I. Polym. Mat. Sci. 1993, 68, 120][Desmarteau, D.D. US Patent 5,463,005 assigned to Gas Research Institute 1995][Kotov, S. V.; Pedersen, S. D.; Qiu, W.; Qiu, Z. M.; Burton, D. J. J. Fluorine Chem. 1996, 82, 13][Feiring, A.E.; Doyle, C.M.; Roelofs, M.G.; Farnham, W.B.; Bekiaran P.G.; Blair H.A.K. WO 99/45048 assigned to Du Pont 1999][Ameduri, B.; Armand, M.; Boucher, M.; Manseri, A. WO 01/49757 assigned to Hydro-Quebec 2001][Ameduri, B.; Boutevin, B.; Armand, M.; Boucher, M. WO 01/49758 assigned to Hydro-Quebec 2001] functionalized by acids (sulfonic, phosphonic or carboxylic) with tetrafluoroethylene (TFE) or also vinylidene fluoride (VDF).

\section{$\underline{\text { 2.2 PEMFC based on aromatic fluorinated polymers }}$}

In the past few decades, attention has been focused into the preparation of aromatic fluoropolymers and this topic was recently reviewed [75], because of the characteristic effects of the aromatic group on the physico-chemical properties (e.g., increasing the $T_{g}$ and the thermostability of the polymer obtained). To the best of our knowledge, it can be observed that aromatic fluorinated macromolecules for PEMFC obtained by membrane by direct (co)polymerization can be prepared from two groups of functionalized aromatic perfluorinated monomer (Figure 1): i) $\alpha, \beta, \beta$-trifluorostyrene (TFS), and ii) $[(\alpha, \beta, \beta$ trifluorovinyl)oxy] benzene (TFVOB).

\section{$\underline{\text { Insert Figure } 1}$}

This section seeks to report the preparation and the characterization of proton exchange membrane for fuel cell (PEMFC) based on aromatic perfluorinated polymers. In a first part, it covers the PEMFC obtained by direct (co)polymerization of functionalized TFS. Various routes dealing with the synthesis and the characterization of PEMFC prepared from 
(co)polymers of functionalized TFVOB have been investigated and are presented in a second part.

\section{$\underline{\text { 2.2.1 PEMFC based on functionalized } \alpha, \beta, \beta \text {-trifluorostyrene }}$}

Several ways dealing with the synthesis of TFS are first reported. In a second way, the preparation and the characterization of PEMFC including (co)polymers of TFS functionalized by acid groups (sulfonic and phosphonic) are mentioned.

\subsubsection{Synthesis and polymerization of $\alpha, \beta, \beta$-trifluorostyrene}

The synthesis of $\alpha, \beta, \beta$-trifluorostyrene (TFS) and its (co)polymerization with different comonomers have been reported by various authors. In 1949, starting from benzene, TFS was initially synthesized by Cohen et al. [76]. In 1953, Prober [77] proposed new synthetic routes starting from sodium difluoroacetate. A general synthetic method to prepared $\alpha, \beta, \beta$ trifluorostyrene was proposed at the end of the 50's by Dixon [78] and Kazennikova et al. [79]. TFS was obtained after a reaction between aryllithium reagents with tetrafluoroethylene. Other synthetic routes were also descriebed by Rybakova et al. [80] in 1976, and Sorokina et al. in 1982 [81]. The most interesting way of TFS synthesis was reported by Heinze and Burton in 1988 [82]. TFS was prepared after a coupling reaction of perfluoroalkenylzinc reagents $\left[\mathrm{F}_{2} \mathrm{C}=\mathrm{CFZnX}\right.$, (Z) $\mathrm{F}_{3} \mathrm{C}-\mathrm{CF}=\mathrm{CF}-\mathrm{ZnX}$, (E) $\mathrm{F}_{3} \mathrm{C}-\mathrm{CF}=\mathrm{CF}-\mathrm{ZnX}$ with $\mathrm{X}$ equivalent of Bromide or Iodide] with aryl iodides in the presence of $\mathrm{Pd}\left(\mathrm{PPh}_{3}\right)_{4}$ as catalyst : to give the corresponding fluoroalkenes (Scheme 1).

\section{Insert Scheme 1}

The synthesis of $p$-Sulfonic acid- $\alpha, \beta, \beta$-trifluorostyrene was patented by Ballard Power System [83] (Scheme 2). First the action of chlorosulfonic acid onto iodobenzene was achieved from the Sanecki's synthesis [84] and the chlorosulfonate or fluorosulfonate trifluorostyrene compound was obtained via a Burton reaction [82]. The corresponding sulfonic acid monomer was obtained by hydrolysis of the $p$-halogenosulfonate- $\alpha, \beta, \beta$ trifluorostyrene. 


\section{Insert Scheme 2}

It has been shown that materials can be prepared by cyclodimerization phenomena of TFS [85-87].

The bulk polymerization of TFS in the presence of benzoyl peroxide at $70-75{ }^{\circ} \mathrm{C}$ and with boron trifluoride at $1-4{ }^{\circ} \mathrm{C}$ was achieved for the first time in 1953 by Prober [77]. Prober investigated also the emulsion copolymerization of $\alpha, \beta, \beta$-trifluorostyrene with styrene, initiated by potassium persulfate at $50{ }^{\circ} \mathrm{C}$ using emulsifiers (sodium tetraborate decahydrate (67\% conversion), Aerosol OT (47\% conversion), Dodecylamine hydrochloride ( $83 \%$ conversion). Softening points of the copolymers were ranging between 207 and $225{ }^{\circ} \mathrm{C}$. Furthermore, in 1981, Tevlina et al. [88] copolymerized $\alpha, \beta, \beta$-trifluorostyrene (I) with vinyl fluoro monomers like $\mathrm{N}$-vinylpyrrolidone (II), $\mathrm{H}_{2} \mathrm{C}=\mathrm{CF}-\mathrm{CN}$ (III), $\mathrm{FHC}=\mathrm{CF}-\mathrm{COOMe}$ (IV) and $\mathrm{F} 2 \mathrm{C}=\mathrm{C}\left(\mathrm{CF}_{3}\right) \mathrm{COOMe}$ in the presence of $\mathrm{AIBN}$. The low reactivity of (I) was related to the presence of fluorine in both $\beta$-position of the vinyl group. The high polarity of bonds in compounds III, IV and V was related to the electron acceptor effect of fluorine. Compounds II, III and IV were highly reactive in copolymerization with I.

\subsubsection{2. poly $(\alpha, \beta, \beta$-trifluorostyrene) incorporated in PFMFC}

p-Chloro or fluorosulfonate- $\alpha, \beta, \beta$-trifluorostyrene synthesized by Stone et al. and patented by Ballard Power System [83] was copolymerized in emulsion (in presence of dodecylamine hydrochloride) with trifluorostyrene functionalized or not (Scheme 3):

\section{$\underline{\text { Insert Scheme } 3}$}

However, the thermal properties ( $\mathrm{Tg}, \mathrm{Td}$ ), the molecular weight, the polydispersity index of copolymers, and the electrochemical properties of the PEMFC like Ion Exchange Capacity (IEC), swelling rates, proton conductivity were not reported.

Interestingly, in 1999, Stone et al. [89] proposed a PEMFC based on phosphonic acid trifluorostyrene. Polymers were prepared from two basic steps (Scheme 4): i) synthesis of 4iodo-benzene phosphonic acid dimethyl ester (4-1), and ii) synthesis of the p-dimethyl 
phosphonate- $\alpha, \beta, \beta$-trifluorostyrene (4-2). This monomer was either homopolymerized or copolymerized (Scheme 4).

\section{Insert Scheme 4}

Although, it is known that $\alpha, \beta, \beta$-trifluorostyrene does not homopolymerize, these authors claimed that homopolymer of monomer (4-2) was first prepared by the authors. They achieved the highest degree of ionization and the lowest equivalent weight for an ionomer of this structure by using a variety of standard techniques including emulsion polymerization, solution polymerization (in toluene), and bulk polymerization. The best yields were obtained in bulk polymerization initiated by AIBN. The prepared membranes were characterized by a low intrinsic viscosity and very poor mechanical properties. Nevertheless, the homopolymer (4-3) was hydrolyzed to afford an ionomer mixture, which was soluble in aqueous base. As a consequence, the physical properties of ionomer did not fulfill the requirements for use these polymers as a proton exchange membrane in a fuel cell.

In a second way, Stone et al. [89] copolymerized monomer (4-2) with $\alpha, \beta, \beta$-trifluorostyrene (TFS) (Scheme 4) by emulsion polymerization in $21 \%$ isolated yield. The optimized ratio between TFS and dimethylphosphonate-substituted- $\alpha, \beta, \beta$-trifluorostyrene monomer in the copolymer (4-5) was $2.4: 1$. The molecular weights of the resulting copolymer were 38100 , and $105900 \mathrm{~g} / \mathrm{mol}$, for $\mathrm{Mn}$ and $\mathrm{Mw}$, respectively.

Furthermore, homopolymer (4-3) (membrane A) was hydrolyzed with acid conditions (hydrochloric acid in dioxane, $100^{\circ} \mathrm{C}, 20$ hours) The yield and the equivalent weight of acid functions were $95 \%$ and $130 \mathrm{~g} / \mathrm{mol}$ respectively. Copolymer (4-4) was hydrolyzed by the authors using two proceeds: i) basic conditions (potassium hydroxide, $84{ }^{\circ} \mathrm{C}$, 64 Hours), membrane $\mathbf{C}_{\mathbf{1}}$, ii) acid conditions with a DMF pre-treatment, membrane $\mathbf{C}_{\mathbf{3}}$. The electrochemical properties of these membranes are gathered in Table 2 and compared with others copolymers bearing phosphonic acid groups. Finally, the authors concluded that the best results were obtained with an acidic hydrolysis and they explained that the membrane based with a sulfonic acid- $\alpha, \beta, \beta$-trifluorostyrene gave better results that those obtained from phosphonic acid homologue.

$\underline{\text { Insert Table } 2}$ 


\subsection{Conclusion}

$\alpha, \beta, \beta$-trifluorostyrene is very interesting monomer which can be synthesized by different ways like the coupling reaction between functional aryl iodides and perfluoroalkenylzinc reagent. This monomer was functionalized by acid group such as chlorosulfonic or phosphonic acid and copolymerized with TFS leading to materials having high molecular weights and good proton exchange properties.

\section{$\underline{\text { 2.2.2 PEMFC based on functionalized }[(\alpha, \beta, \beta \text {-trifluorovinvl }) \text { oxy }] \text { benzene }}$}

In this subsection, two main kinds of aromatic PEMFC incorporating functionalized $[(\alpha, \beta, \beta-$ trifluoroethenyl)oxy] benzene (TFVOB) are presented: i) polymers prepared by thermocyclodimerization, ii) and macromolecules obtained by direct (co)polymerization of TFVOB with commercially available fluoroalkenes.

\subsubsection{PEMFC prepared by direct thermal cyclodimerization of TFVOB}

$[(\alpha, \beta, \beta$-trifluorovinyl)oxy]benzene and polymers incorporating such a monomer are very interesting materials [75,92], and have received attention by various groups [93-100], industries [92,101-104], and are currently used as materials for microphonic [105], optics [106-109], liquid crystalline [110-112], interlayer dielectrics [113-114], circuit board laminates [115], coating applications [116,117], ionomer membrane and fuel cell $[83,89,118]$, and for the preparation of ion exchange resins [99,104,119].

The most interesting properties of perfluoroalkyl $[(\alpha, \beta, \beta$-trifluorovinyl)oxy] benzene is to undergo thermal cyclopolymerization $[2 \pi+2 \pi]$ with temperature (up to $150{ }^{\circ} \mathrm{C}$ ) (Scheme 5 ). The formed perfluoroalkylpolymers is a thermoplastic and thermoset perfluorocyclobutane (PFCB) [95,99, 120-125].

\section{Insert Scheme 5}


Initially invented by Beckerbauer [120] in 1968, the preparation of functionalized TFVOB has been a breakthrough in numerous investigations [92,95,104,117,123,126-128]. As explained in former communications $[129,130]$ the different trifluorovinyl ethers were usually prepared in two steps: the first one concerned a fluoroalkylation with $\mathrm{BrCF}_{2} \mathrm{CF}_{2} \mathrm{Br}$ while the second one deals with a zinc mediated elimination (Scheme 6).

\section{Insert Scheme 6}

As a matter of fact, Babb et al. $[123,126]$ developed a series of TFVOB prepared from bisand trisphenols, such as, tris(hydroxyphenyl)ethane and biphenol. These different perfluorinated aryl ethers were thermocyclodimerized and led to thermoset polymers $(\mathrm{Tg}=18$ ${ }^{\circ} \mathrm{C}$ ) with good thermal stability (they are stable up to $434{ }^{\circ} \mathrm{C}$ ), thermal/oxidative stability and mechanical properties $[117,124]$.

Furthermore, in 1996, Smith and Babb [95] prepared perfluorocyclobutane aromatic polyethers with a siloxane group. Their syntheses involved an aryl Grignard reagent from 4[(trifluorovinyl)oxy)]bromobenzene that led to a high-yield $(87 \%)$ synthesis of 4 [(trifluorovinyl)oxy]phenyldimethylsilane. The latter was finally dehydrogenatively hydrolyzed in situ and then condensed to yield bis[1,3-[4-[(trifluorovinyl)oxy]phenyl]]1,1,3,3-tetramethyldisiloxane in $43 \%$ yield. Such a monomer was thermocyclodimerized (by heating the monomer at $210{ }^{\circ} \mathrm{C}$ for 14 hours) to yield siloxane perfluorocyclobutane.

In 2000, Smith et al. [117] reported the synthesis of different perfluorocyclobutane (PFCB) polyarylethers (Scheme 7).

\section{Insert Scheme 7}

Interestingly, the reactive grignard [131] or lithium [127,132,133] compound of 4[(trifluorovinyl)oxy)]bromobenzene [95] gained access to an increasing number of organic/inorganic fluorinated compounds [95,127,132,133-138].

The current intensified interests in the preparation of PEMFC based on electrolyte polymers has prompted us to develop the syntheses of aromatic monomers such as trifluorovinyl ethers functionalised by acid groups. In particular, they reported the preparation of $4-[(\alpha, \beta, \beta-$ trifluorovinyl)oxy] benzene phosphonic acid [128] which was hence pioneered (Scheme 8). 
The $[(\alpha, \beta, \beta$-trifluorovinyl)oxy] benzene dialkyl phosphonate was prepared according to various methods of phosphonation like a Michaelis-Arbuzov or a Michaelis-Becker or a palladium catalysed arylation in the presence of various reactants. It was shown that reaction involving a palladium triphenyl phosphine catalyst led to the best yield.

\section{Insert Scheme 8}

Ford et al. [133] reported in 2000, the synthesis of aromatic perfluorovinyl ether monomers containing the sulfonamide and the sulfonic acid functionality for different applications such as the preparation of proton exchange membrane fuel cell [139-142]. As the former exemple, Ford et al. used a [p-((trifluorovinyl)oxy)phenyl]lithium which was cross-coupling with $\mathrm{FSO}_{2} \mathrm{Cl}$ to give 4-[(trifluorovinyl)oxy] benzenesulfonyl chloride in a 65\% yield ((9-1), Scheme 9).

\section{Insert Scheme 9}

Monomers (9-2), (9-3) and (9-4) were prepared in 91, 85 and 80\% yield respectively. The thermal behavior of monomer (9-3) has been studied in DSC. The exothermic polymerization begins at $175^{\circ} \mathrm{C}\left(\mathrm{T}_{\text {onset }}\right)$ and $214\left(\mathrm{~T}_{\max }\right)$.

These different monomers which have similar structure as that of monomer (9-1) (Scheme 9) and polymers prepared by thermocyclodimerization of these monomers were patented by $3 \mathrm{M}$ Innovative Properties Company [104] in 2001 (Scheme 10) for Proton exchange membrane fuel cell applications.

\section{Insert Scheme 10}

\subsubsection{PEMFC prepared by direct radical terpolymerization of $\alpha, \beta, \beta$-trifluorovinyl benzyl}

ethers

More recently, Souzy et al. [143] studied the radical homo-, co-, and terpolymerization of 4$[(\alpha, \beta, \beta$-trifluorovinyl)oxy] bromobenzene with commercially available fluoroalkenes such as vinylidene fluoride (VDF) and / or chlorotrifluoroethylene (CTFE), and / or 
hexafluoropropene (HFP), and/or Perfluorovinyl methyl ether (PMVE) (Scheme 11). As mentioned above, $\alpha, \beta, \beta$-trifluorovinyl benzyl ethers are interesting monomers because they can lead to thermostable fluoropolymers. Authors optimized the conditions of co- and terpolymerization and even tetrapolymerization in terms of the nature of the radical initiators, of the nature of solvents (fluorinated or non-halogenated and the relative reactivities of the comonomers). Furthermore, they synthesized terpolymers incorporating $4-[(\alpha, \beta, \beta-$ trifluorovinyl)oxy] bromobenzene and showed that the VDF/PMVE blend enhanced the incorporation of the $\alpha, \beta, \beta$-trifluorovinyl benzyl ethers.

\section{$\underline{\text { Insert Scheme } 11}$}

Using the optimal experimental conditions of radical terpolymerization of $4-[(\alpha, \beta, \beta-$ trifluorovinyl)oxy] bromobenzene with the fluoroalkenes above and performing in solution in 1,1,1,3,3-pentafluorobutane initiated by 2,5-bis(tert-butylperoxy)-2,5-dimethylhexane, these authors have reported the synthesis of new polymer electrolyte membranes based on fluoropolymers incorporating aromatic perfluorovinyl ether sulfonic acids [92,144]. As a matter of fact, they described a novel synthetic route for the preparation of perfluorovinyl ether monomer containing sulfonic functionalities, 4-[( $\alpha, \beta, \beta$-trifluorovinyl)oxy]benzene sulfonic acid (TFVOBSA) synthesized in a $72 \%$ overall yields, and presented the radical (co) and terpolymerization of $4-[(\alpha, \beta, \beta$-trifluorovinyl)oxy]benzene sulfonyl chloride (TFVOBSC) with VDF, HFP, and PMVE (Scheme 12). The incorporation of the aromatic functional monomer was yet limited $9 \%$ and it was noted that the higher the feed content, the lower yield. Poly(VDF-ter-HFP-ter-TFVOBSC) and Poly(VDF-ter-PMVE-ter-TFVOBSC) were hydrolyzed by basic treatment without changing the content of fluoromonomers in the terpolymers. Moreover, membranes were formulated with a commercially available fluoropolymer by casting and led to good film-forming properties. The IEC values were ranging between 0.4 and $0.6 \mathrm{mEq} / \mathrm{g}$, the corresponding protonic conductivities and swelling rates were characterized and the thermal properties studied. It indicates that these materials incorporated sulfonic acids. Although conductivity values, still in improvement, and ranging between 0.01 and $0.1 \mathrm{mS} . \mathrm{cm}^{-1}$, yet far from that of Nafion ${ }^{\circledR}$ (see Table 3).

\section{Insert Scheme 12}

\section{$\underline{\text { Insert Table } 3}$}




\section{$\underline{\text { 2.2.2.3 Conclusion }}$}

$[(\alpha, \beta, \beta$-trifluorovinyl)oxy] benzene are very interesting materials which could undergo thermal cyclopolymerization giving low molecular weight perfluoroalkylpolymers and provide high-Tg thermoset polymers with good thermal stability. Moreover, most of the functional organic/inorganic monomers incorporating a trifluorovinyl ether group are obtained by a coupling reaction between a reactive Grignard or lithium agent functionalized by a trifluorovinyloxy function and various electropilic compounds. These perfluorinated aryl ethers are currently used for the preparation of ion exchange resins and ionomer membranes.

Recently, investigations dealing with radical terpolymerization of those aromatic fluoromonomers functionalized by sulfonic acid groups with VDF, CTFE, HFP and PMVE led to fluoropolymers bearing acid functionality with yet low yield and the conductivity.

\section{$\underline{\text { Conclusion }}$}

Fluorinated aromatic polymers have a unique combination of high performance properties and can be used, despite their high price, in high performance application such as aerospace, aeronautics, microelectronics, coating, and represent a new and interesting generation material for Proton Exchange Membrane Fuel Cell (PEMFC). This chapter has shown that many ways are possible to achieve the preparation of various kinds of fluoromonomers: trifluorostyrene (TFS) and the (trifluorovinyl)oxy benzene (TFVOB) monomers and their (co)polymeryzations have also been studied.

The first part dealt with the synthesis and (co)polymerization of TFS. The TFS preparation was achieved by using different coupling reaction of functional aryl iodides with perfluoroalkenylzinc reagent. TFS can homopolymerize and copolymerize under emulsion process. Nevertheless, the (co) and terpolymerization of TFS functionalized by phosphonic or sulfonic acid groups are very intersting materials for wave guides or proton exchange properties.

Second, aromatic trifluorovinyl ethers is based on a nucleophilic substitution of a functionalized phenolate onto 1,2-dibromotetrafluoroethane $\left(\mathrm{BrCF}_{2} \mathrm{CF}_{2} \mathrm{Br}\right)$ followed by a dehalogenation reaction. It is worth mentioning that, aromatic trifluorovinyl ethers undergo 
thermal cyclopolymerization giving material characterized by good physical properties. PEMFC can be prepared from polymers incorporating such a monomer. Two ways could be used: i) the first one is based on polymers obtained by thermocyclodimerization $[2 \pi+2 \pi]$, and ii) the second one dealt with the direct radical terpolymerization of these aromatic trifluorovinyl ethers with fluoroolefins such as vinylidene fluoride, hexafluoropropene, perfluoromethylvinyl ether or chlorotrifluoroethylene. The PEMFC prepared with the second category of poly(TFVOB) are still investigated and could lead to very interesting materials having proton exchange properties.

Such new promising proton exchange membrane or wave guides materials are nowadays real challenges for fuel cell applications and for the optic industry, and should attract the interest of many academic and industrial researchers.

\section{Acknowledgements}

The authors acknowledge the Centre National de la Recherche Scientifique, the French consorption GDR PACEM 2479, and the Commissariat à l'Energie Atomique for the financial support of the $\mathrm{PhD}$ studies (to R.S.). 


\section{References}

[75] R. Souzy, B. Ameduri, B. Boutevin, Prog. Polym. Sci. 29(2) (2004) 75-106.

[76] S. G. Cohen, H. T. Wolosinski, P. J. Scheuer, J. Am. Chem. Soc. 71 (1949) 34393440 .

[77] M. Prober, J. Am. Chem. Soc. 75 (1953) 968-973.

[78] S. Dixon, J. Org. Chem. 21 (1956) 400-403.

[79] G. V. Kazennikova, T. V. Talamaeva, A. V. Zimin, A. P. Simonov, K. A. Kocheshkov, Izv. Akad. Nauk SSSR, Otd. Khim. Nauk (1961) 1063-1065.

[80] L. F. Rybakova, E. .M. Panov, A. A. Nikitina, K. A. Kocheshkov, I. V. Karandi, Zhurnal Obshchei Khimii 46(1) (1976) 117-121.

[81] R. S. Sorokina, L. F. Rybakova, I. O. Kalinovskii, V. A.Chernoplekova, I. P. Beletskaya, Zh. Org. Khim. 18(11) (1982) 2458-2459.

[82] P. L. Heinze, D. J. Burton, J. Org. Chem. 53(12) 1988 2714-2720.

[83] C. Stone, A. E. Steck, R. D. Lousenberg (Ballard Power Systems Inc.), US 5602185, (1997).

[84] P. Sanecki, Polish J. Chem. 66(1) (1992) 101-110.

[85] R. B. Hodgdon, D. I. MacDonald, J. Polym. Sci., Part A-1 (Polymer Chemistry Edition) 6(3) (1968) 711-717.

[86] P. D. Barlett, G. M. Cohen, J. Am. Chem. Soc. 95(23) (1973) 7923-7925.

[87] F. Tellier, R. Sauvetre, J. F. Normant, J. Organomet. Chem. 331(3) (1987) 281-2981. 
[88] A. S. Tevlina, A. N. Ivankin, V. V. Korshak, N. P. Baranova, T. S. Nikitina, E. M. Rokhlin, Mosk. Khim. Tekhnol. Inst., Moscow, USRR, deposited Doc. 1981, Viniti Chem. Abst., 127(81) (1981) 12-24.

[89] C. Stone, T. S. Daynard, L. Q. Hu, C. Mah, A. E. Steck, J. New Mater. Electrochem. Syst. 3(1) (2000) 43-50.

[90] X. Xu, I. Cabasso, Poly. Mat. Sci.,Eng. (Am. Chem. Soc., Div. PMSE) 68 (1993) 120121.

[91] S. V. Kotov, S. D. Pedersen, W. Qiu, Z. M. Qiu, D. J. Burton, J. Fluorine Chem. 82(1) (1997) 13-19.

[92] M. Pineri, D. Marsacq, B. Ameduri, R. Souzy (Commissariat à l'Energie Atomique) French Patent, 2,843,398 (2004).

[93] M. Watanabe, H. Ishiuchi, JP 5,013,070 (1993).

[94] Z. Y. Yang, A.E. Feiring, B. E. Smart, J. Am. Chem. Soc. 116(9) (1994) 4135-4136.

[95] D. W. Jr Smith, D. A. Babb, Macromolecules 29(3) (1996) 852-860.

[96] K. P. U. Pereta, M. Krawiek, D. W. Jr Smith, Tetrahedron 58 (2002) 10197-10203.

[97] J. Luo, S. Liu, M. Haller, L. Liu, H. Ma, A. K. Y. Jen, Adv. Mater. 14(23) (2002) 1763-1768.

[98] C. M. Topping, J. Jin, S. C. Jr Ligon, A. V. Patil, S. Fallis, J. A. Irvin, D. D. Desmarteau, D. W. Jr Smith, Polym. Prepr. (Am. Chem. Soc. Div. Polym. Chem.) 43(1) (2002) 486-487.

[99] S. C. Jr Ligon, M. Krawieck, A. Kitaygorodskiy, D. W. Jr Smith, J. Fluorine Chem. $123(1)(2003)$ 139-146. 
[100] F. L. Qing, R. Wang, B. Li, X. Zheng, W. D. Meng, J. Fluorine Chem. 120(1) (2003) 21-24.

[101] K. S. Clement, B. R. Ezzel, D. A. Babb, W. F. Richey (Dow Chemical) US 5,037,919 (1991).

[102] K. S. Clement, B. R. Ezzel, D. A. Babb (Dow Chemical). US 5,021,602 (1991).

[103] E. Bartmann, H. Plach, R. Eidenschink, V. Reiffenrath, D. Pauluth, E. Poetsch, S. Schoen, V. Meyer V.; M. Junge, R. Hittich (Merck). US 5,403,512 (1995).

[104] D. D. Desmarteau, C. W. Martin, L. A. Ford, Y. Xie (3M Innovative Properties company). US 6,268,532 (2001).

[105] D. W. Jr Smith, S. Chen, S. Kumar, J. Ballato, H. Shah, C. Topping, S. Foulger, Adv. Mater. 14(21) (2002) 1585-1589.

[106] S. H. Foulger, P. Jiang, A. Lattam, D. W. Jr Smith, J. Ballato, Langmuir 17 (2001) $6023-6026$

[107] S. H. Foulger, A. Lattam, J. Ballato, P. Jiang, Y. Ying, D. W. Jr Smith, Adv. Mater. 13(24) (2001) 1898-1901.

[108] H. Zengin, W. Zhou, J. Jin, R. Czerw, D. W. Jr Smith, L. Echegoyen, D. Caroll, S. Foulger, J. Ballato, Adv. Mat. 14(20) (2002) 1480-1483.

[109] J. Luo, S. Liu, M. Haller, L. Liu, H. Ma, A. K. Y. Jen, Adv. Mat. 14(23) $20021763-$ 1768 .

[110] D. W. Jr Smith, H. W. Boone, R. Traipho1, H. Shah, D. Perahia, Macromolecules 33(4) (2000) 1126-1128.

[111] R. Traiphol, H. V. Shah, D. W. Jr Smith, D. Perahia, Macromolecules 34(12) (2001) 3954-3961. 
[112] R. Traiphol, D. W. Jr Smith, D. Perahia, J. Polym. Sci. Part A (Polym. Chem.) 40(24) (2002) 2817-2824.

[113] P. H. Townsend, E. O. Shaffer, M. E. Mills, J. Blackson, M. J. Radler, Materials Research Society Symposium Proceedings, 443(Low-Dielectric Constant Materials II) (1997) 33-40.

[114] G. Fishbeck, R. Moosburger, C. Kostrzewa, A. Achen, K. Petermann, Electronics Letters 33(6) (1997) 518-519.

[115] D. Perretie, L. Bratton, J. Bremmer, D. A. Babb, Q. Chen, J. H. Judy, Proceedings of SPIE-The International Society for Optical Engineering, 1911 (Liquid Crystal Materials, Devices, and Applications II) (1993) 15-20.

[116] T. A. Jr Tumolillo, A. Thomas, P. R. Ashley, Appl. Phys. Lett. 62(24) (1993) 30683070

[117] D. W. Jr Smith, D. A. Babb, H. Shah, A. Hoeglund, R. Traiphol, D. Perahia, H. Boone C. Langhoff, M. Radler, J. Fluorine Chem. 104(1) (2000) 109-117.

[118] C. W. Martin, P. J. Nandapurkar, S. S. Katti, In Polymeric Materials Encyclopedia; CRC Press Inc., Boca Raton, FL.

[119] W. G. Grot, C. J. Molnar, P. R. Resnick (DuPont de Nemours), AU 544,027 (1985).

[120] R. Beckerbauer (DuPont de Nemours), US 3,397,191 (1968).

[121] D. A. Babb, K. S. Clement, B. R. Ezzel (Dow Chemical), US 5,023,380 (1991).

[122] D. A. Babb, K. S. Clement, W. F. Richey, B. R. Ezzel (Dow Chemical), US 5,037,917 (1991) 
[123] D. A. Babb, R. B. Ezzel, K. S. Clement, W. F. Richey, A. P. Kennedy, J. Polym. Sci. Part A : Polym. Chem. 31(13) (1993) 3465-3477.

[124] A. P. Kennedy, D. A. Babb, J. N. Bremmer, A. J. Jr Pasztor, J. Polym. Sci. : Part A : Polym. Chem. 33(11) (1995) 1859-1865.

[125] D. A. Babb, N. G. Rondan, D. W. Jr Smith, Polym. Prepr. (Am. Chem. Soc., Div. Polym. Chem.) 36(1) (1995) 721-722

[126] D. A. Babb, K. S. Clement, B. R. Ezzel (Dow Chemical), US 5, 159,038 (1992).

[127] J. Ji, S. Narayan-Sarathy, R. H. Neilson, J. D. Oxley, D. A. Babb, N. G. Rondan, D. W. Jr Smith, Organometallics 17(5) (1998) 783-785.

[128] R. Souzy, B. Ameduri, B. Boutevin, D. Virieux, J. Fluorine Chem., in press.

[129] D. A. Babb, R. V. Snelgrove, D. W. Jr Smith, S. F. Mudrich, ACS Symposium Series (1996), 624(Step-Growth Polymers for High-Performance Materials) (1996) 431-441.

[130] H. W. Boone, D. W. Jr Smith, D. A. Babb, Polym. Prepr. (Am. Chem. Soc. Div. Polym. Chem.) 39(2) (1998) 812-813.

[131] Y. Xu, D. C. Loveday, J. P. Ferraris, D. W. Jr Smith, Polym. Prepr. (American Chemical Society, Division of Polymer Chemistry) 39(1) (1998) 143-144.

[132] S. Narayan-Sarathy, R. H. Neilson, D. W. Jr Smith, Polym. Prepr., (Am. Chem. Soc. Div. Polym. Chem.) 39(1) (1998) 609-610.

[133] L. A. Ford, D. W. Jr Smith, D. D. Desmarteau, Polym. Mater. Sci. Eng. (Am. Chem. Soc., Div. PMSE) 83 (2000) 10-11.

[134] R. H. Neilson, H. Robert, J. Ji, S. Narayan-Sarathy, J. Oxley, D. W. Jr Smith, Book of Abstracts, 213th ACS National Meeting, San Francisco, April 13-17 1997. 
[135] D. A. Babb, H. W. Boone, D. W. Jr Smith, P. W. Rudolph, J. Appl. Polym. Sci., 69(10) (1998) 2005-2012.

[136] H. W. Boone, D. W. Jr Smith, D. A. Babb, Polym. Prepr. (Am. Chem. Soc. Div. Polym. Chem.) 39(2) (1998) 812-813.

[137] J. Rizzo, F. W. Harris, Polym. Prepr. (Am. Chem. Soc. Div. Polym. Chem.) 40(2) (1999) 874-875.

[138] J. Rizzo, F. W. Harris, Polymer 41(13) (2000) 5125-5136.

[139] D. D. DesMarteau, J. Fluorine Chem. 72(2) (1995) 203-208.

[140] D. D. DesMarteau, J. J. Ma, M. H. Tu, J. T. Liu, B. Thomas, J. McClellan, Polym. Mat. Sci. \& Eng. (Am. Chem. Soc., Div. PMSE) 80 (1999) 598-599.

[141] S. E. Creager, S. Savett, B. Thomas, D. D. DesMarteau, Polym. Mat. Sci. \& Eng. (Am. Chem. Soc., Div. PMSE), (Polymeric Materials Science and Engineering) 80 (1999) 600 .

[142] S. E. Creager, J. J. Summer, R. D. Baily, J. J. Ma, W. T. Pennington, D. D. DesMarteau, Electrochem. Solid State Lett 2(9) (1999) 434-436.

[143] R. Souzy, B. Ameduri, B. Boutevin, J. Polym. Sci., Part A: Polym. Chem., in press.

[144] R. Souzy, B. Ameduri, B. Boutevin, P. Capron, D. Marsacq, G. Gebel, submited to Fuel Cell - From fundamentals to Systems.

[145] A. Balland-Longeau, F. Pereira, P. Capron, R. Mercier (Commissariat à 1'Energie Atomique), Fr Patent 2,843,398 (2004).

[146] C. Leninivin, PhD dissertation, Poitiers University (2003). 


\section{TABLES}

Table 1: non-fluorinated polymers used in PEMFC

Table 2: Electrochemical characteristics of different ionomer membranes achieved by Stone et al. [89], Xu and Cabasso [90], and Kotov et al. [91].

Table 3 : Ionic exchange capacities and proton conductivities of different PEMFC. 
Table 1: non-fluorinated polymers used in PEMFC

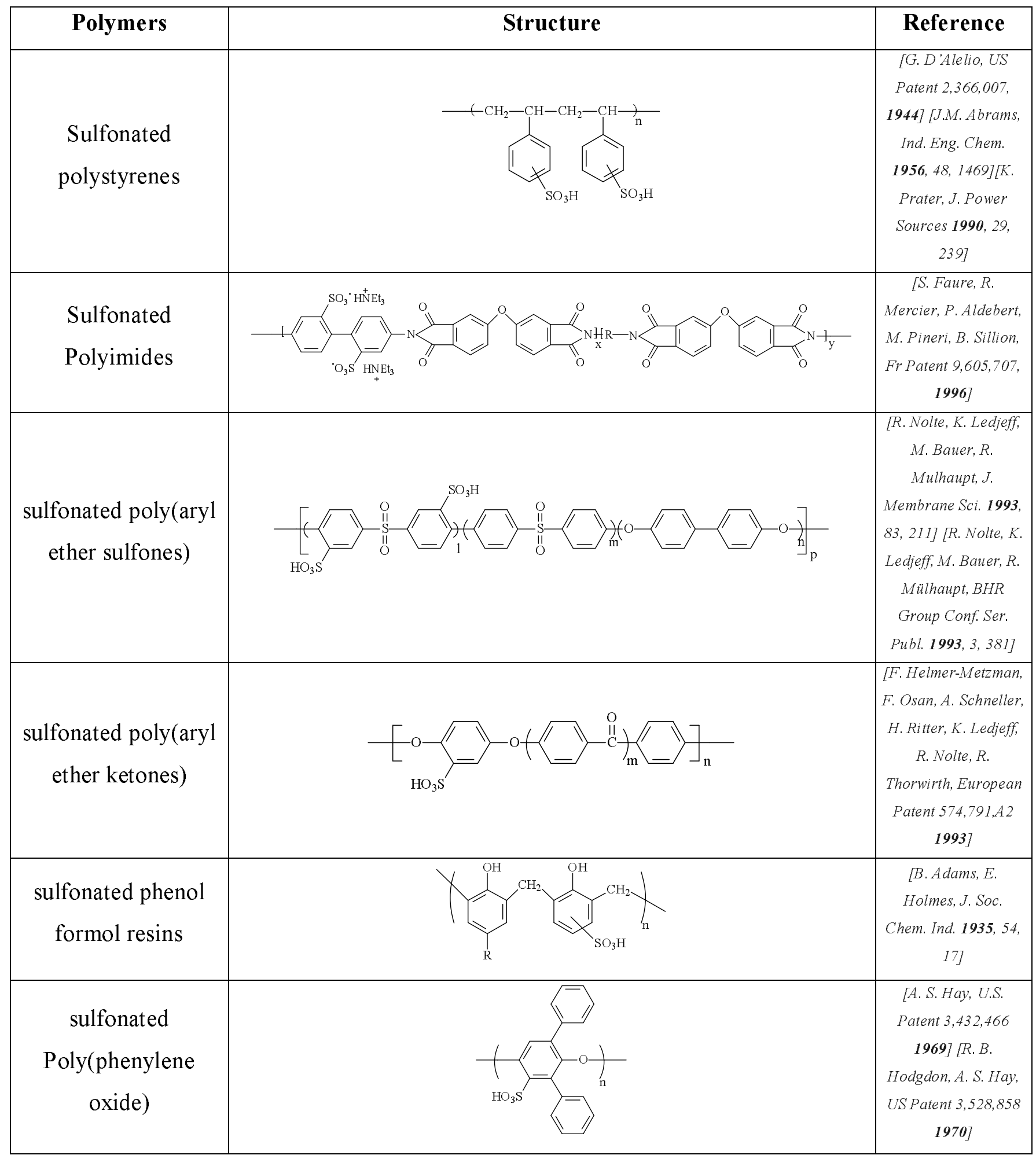




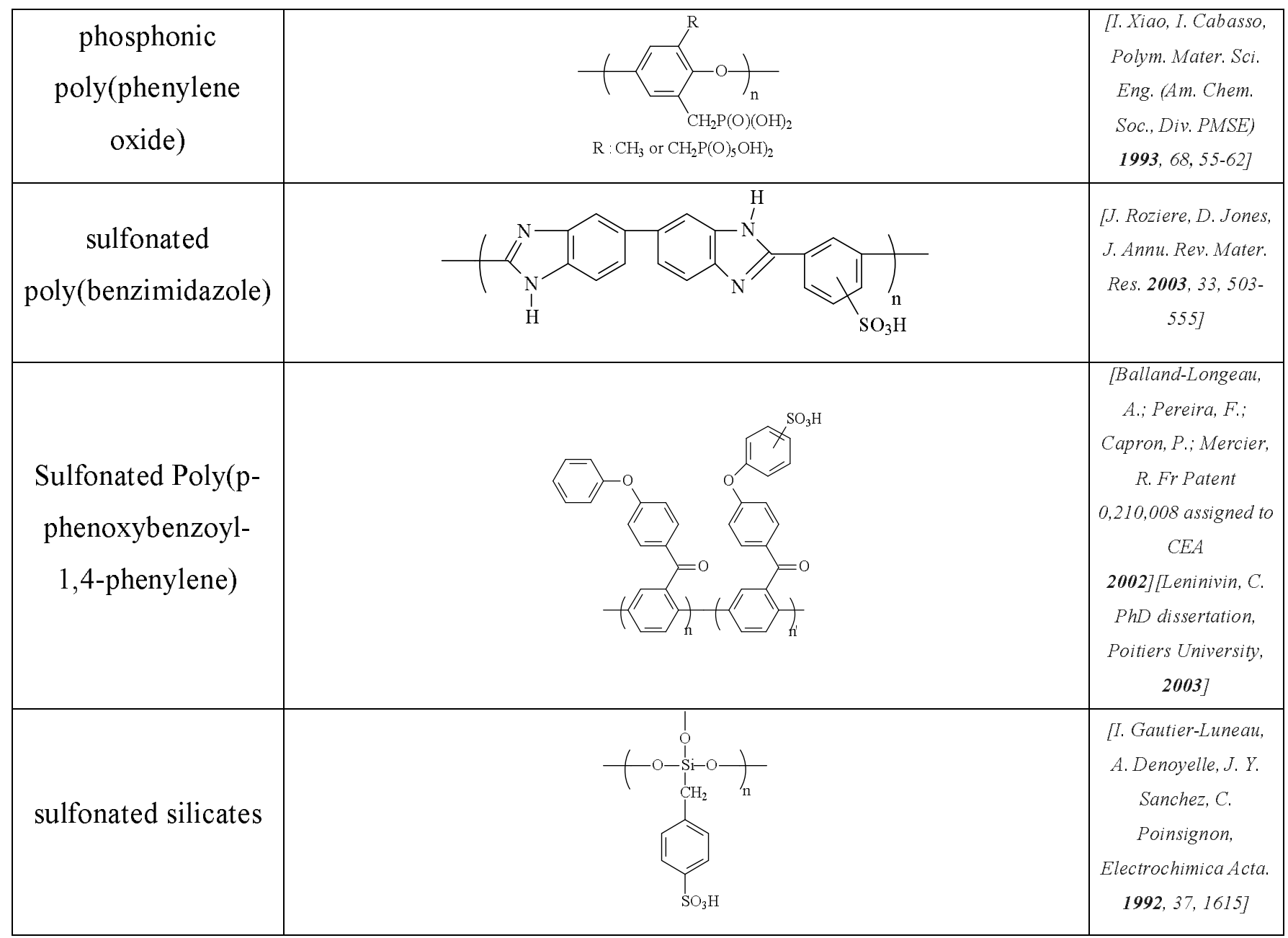


Table 2: Electrochemical characteristics of different ionomer membranes achieved by Stone et al. [89], Xu and Cabasso [90], and Kotov et al. [91].

\begin{tabular}{|c|c|c|c|c|c|}
\hline Ionomer & $\begin{array}{c}\mathrm{EW} \\
(\mathrm{g} / \mathrm{mol} \\
)\end{array}$ & $\begin{array}{c}\text { EW } \\
\text { effective } \\
(\mathrm{g} / \mathrm{mol})^{1}\end{array}$ & $\begin{array}{c}\text { Transverse Proton } \\
\text { Conductivity }(\mathrm{S} / \mathrm{cm} \\
\left.\times 10^{2}\right) \\
\end{array}$ & $\begin{array}{c}\text { Water } \\
\text { absorption at } \\
100^{\circ} \mathrm{C}(\%) \\
\end{array}$ & $\underline{\text { Reference }}$ \\
\hline $\begin{array}{l}\text { A (membrane based on } \\
\text { homopolymer 27-4) }\end{array}$ & 130 & 215 & - & - & [89] \\
\hline $\begin{array}{l}C_{1} \text { (membrane hased on } \\
\text { copolymer 28-2) }\end{array}$ & 350 & 670 & $0.01-0.001$ & 15 & [89] \\
\hline $\begin{array}{l}\mathrm{C}_{3} \text { (membrane hased on } \\
\text { copolymer 28-2) }\end{array}$ & 200 & 380 & - & 77 & [89] \\
\hline $\begin{array}{c}\text { D (membrane based on } \\
3,86: 1 \text { ration }: \text { m }\left[C F_{2^{-}}\right. \\
\left.C_{2}\right]_{n}\left[\mathrm{CF}_{2}-\mathrm{CFX}\right]_{\mathrm{m}} \text { with X }= \\
\left.\mathrm{O}\left(\mathrm{CF}_{2}\right)_{3} \mathrm{P}(\mathrm{O})(\mathrm{OH})_{2}\right)\end{array}$ & 357 & 357 & 7.6 & 22 & [91] \\
\hline $\begin{array}{c}\mathrm{E} \text { (membrane based on } \\
4,63: 1 \text { ratio } \mathrm{n}: \mathrm{m}\left[\mathrm{CF}_{2^{-}}\right. \\
\left.\mathrm{CF}_{2}\right]_{n}\left[\mathrm{CF}_{2}-\mathrm{CFX}\right]_{\mathrm{m}} \text { with X }= \\
\left.\mathrm{O}\left(\mathrm{CF}_{2}\right)_{3} \mathrm{P}(\mathrm{O})(\mathrm{OH})_{2}\right)\end{array}$ & 370 & 370 & 6.9 & 21 & [91] \\
\hline $\begin{array}{l}\text { F (membrane based on } \\
\text { poly(dimethylphenylene oxide } \\
\text { phosphonic acid)) }\end{array}$ & 111 & 202 & - & - & {$[90]$} \\
\hline $\begin{array}{l}\text { G (membrane based on } \\
\text { poly(dimethylphenylene oxide } \\
\text { diphosphonic acid)) }\end{array}$ & 70 & 107 & - & - & [90] \\
\hline
\end{tabular}


Table 3 : Ionic exchange capacities and proton conductivities of different PEMFC

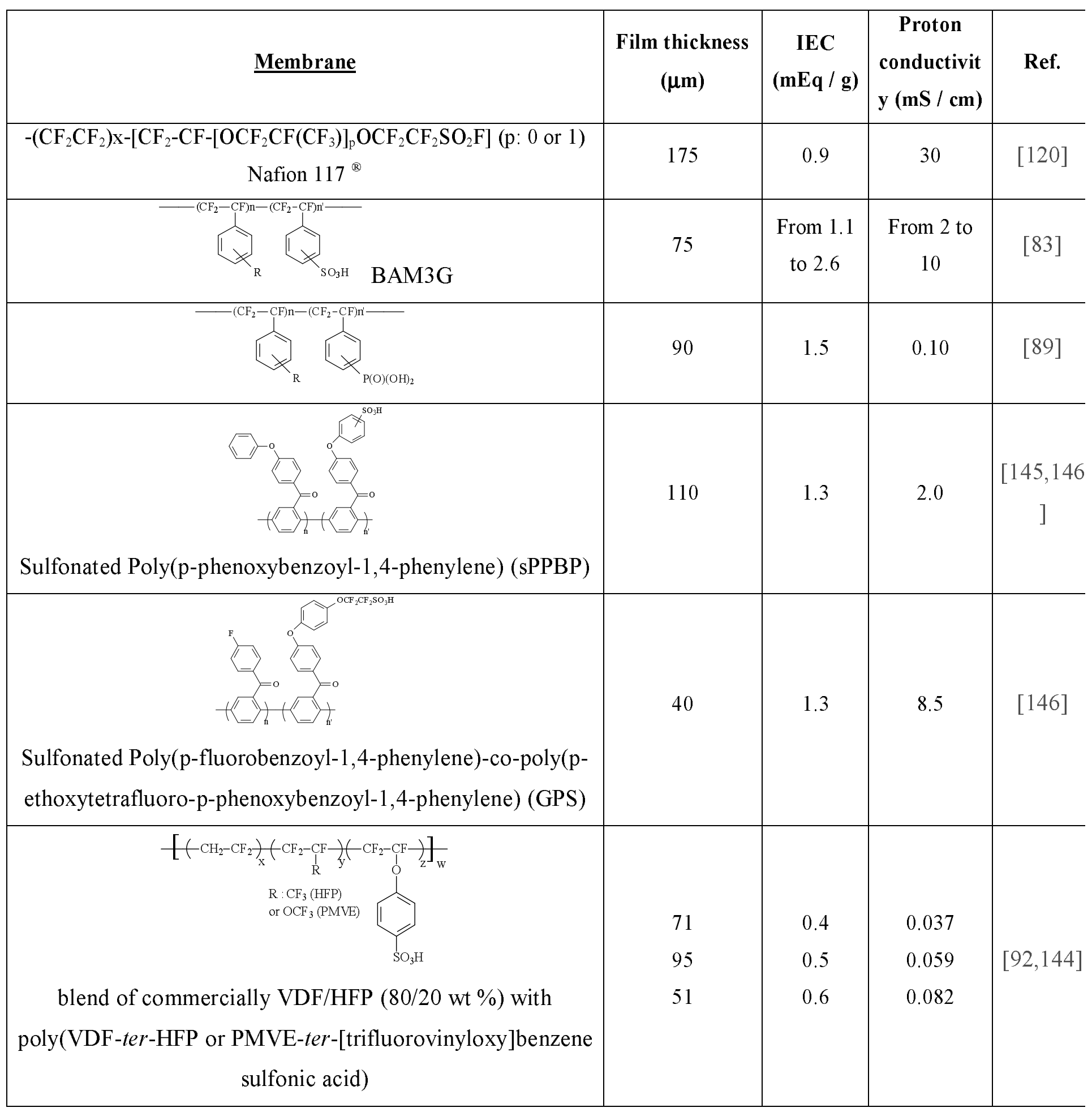




\section{FIGURES}

Figure 1: General structure of functionalized TFS and TFVOB 
Figure 1: General structure of functionalized TFS and TFVOB

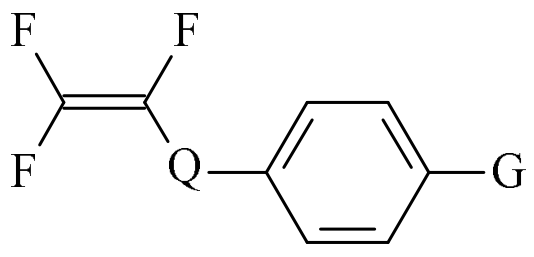

TFS: Q equivalent to “-“, TFVOB: Q equivalent to O $\mathrm{G}$ : sulfonic or phosphonic acid 


\section{SCHEMES}

Scheme 1: Synthesis of $\alpha, \beta, \beta$-trifluorostyrene by Heinze and Burton [82].

Scheme 2: $\quad$ Synthesis of 4-fluorosulfonate- $\alpha, \beta, \beta$-trifluorostyrene [83].

Scheme 3: Copolymerization of fluorosulfonate- $\alpha, \beta, \beta$-trifluorostyrene [83].

Scheme 4: Synthesis and homopolymerization of dimethylphosphonate-4-substituted$\alpha, \beta, \beta$-trifluorostyrene according to Stone et al. [89].

Scheme 5: Formation of aromatic perfluorocyclobutane (PFCB) [95,99, 120-125].

Scheme 6: General synthetic route of TFVOB preparation

Scheme 7: Poly aryl vinyl ether synthesized by Smith et al. [117].

Scheme 8: Synthesis of new aromatic perfluorovinyl ether monomers containing phosphonic acid functionality [128].

Scheme 9: Synthesis of aromatic perfluorovinyl ether monomers containing the sulfonamide and the sulfonic acid functionality according to Ford et al. [133]

Scheme 10: Functionnalised polyarylene vinyl ethers according to $3 M$ Innovative Properties company [104].

Scheme 11: Terpolymerization of $4-[(\alpha, \beta, \beta$-trifluorovinyl)oxy] bromobenzene with Fluoroalkenes (VDF, HFP, PMVE and CTFE) [143].

Scheme 12: Radical terpolymerization (I) of TFVOBSC with VDF and / or HFP and / or PMVE, and hydrolysis (II) of the correponding terpolymers [92,144]. 
Scheme 1: $\quad$ Synthesis of $\alpha_{,} \beta, \beta$-trifluorostyrene by Heinze and Burton [82].

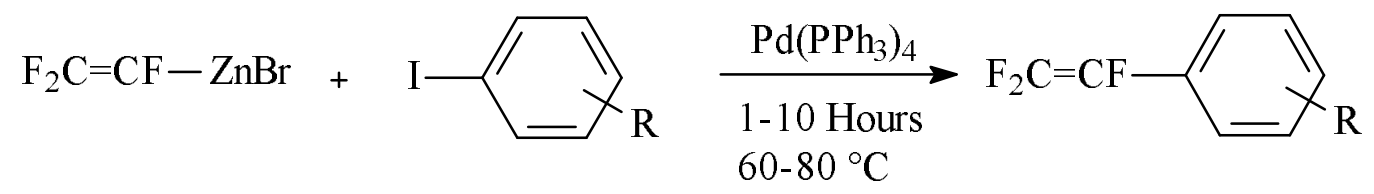


Scheme 2: $\quad$ Synthesis of 4-fluorosulfonate- $\alpha, \beta, \beta$-trifluorostyrene [83].

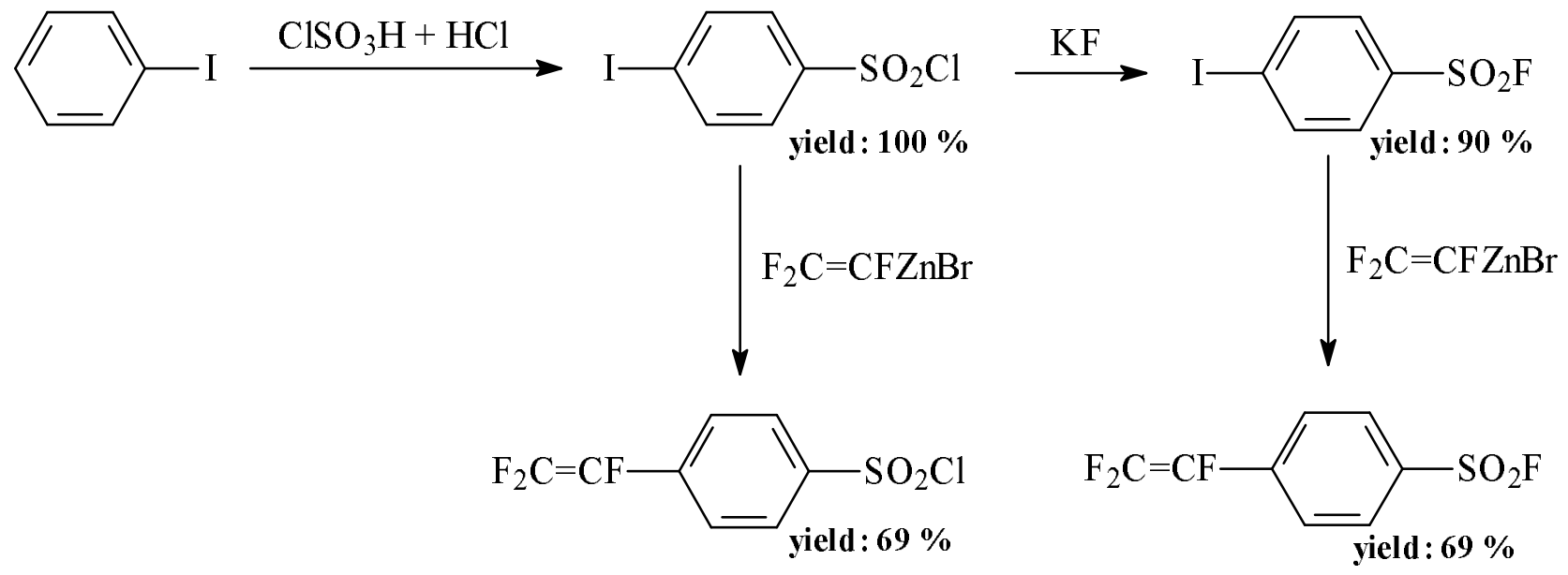


Scheme 3: $\quad$ Copolymerization of fluorosulfonate- $\alpha, \beta, \beta$-trifluorostyrene [83].
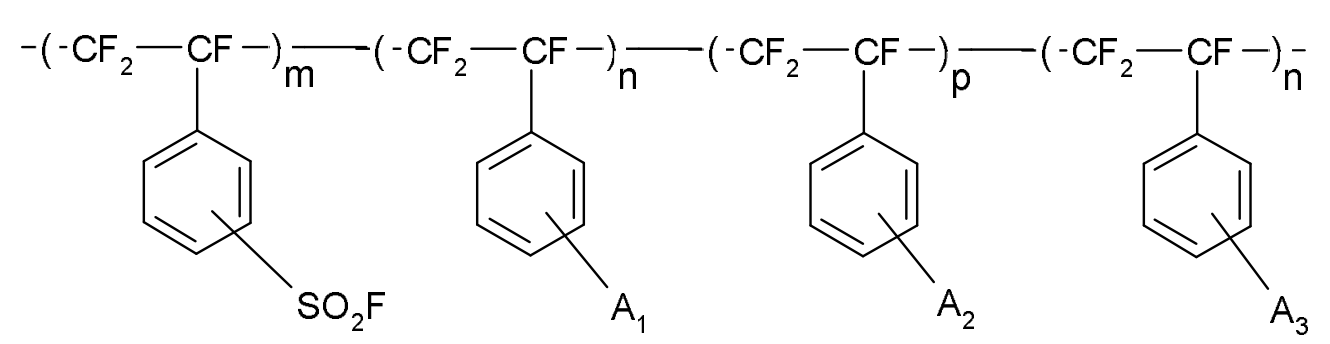

$\mathrm{m}, \mathrm{n}, \mathrm{p}, \mathrm{q}>0$

$\mathrm{A}_{1}, \mathrm{~A}_{2}, \mathrm{~A}_{3}: \mathrm{CF}=\mathrm{CF}_{2}, \mathrm{CN}, \mathrm{NO}_{2}, \mathrm{OH}, \mathrm{OR}, \mathrm{SO}_{3} \mathrm{H}, \mathrm{PO}_{2} \mathrm{H}_{2}, \mathrm{PO}_{3} \mathrm{H}_{2}, \mathrm{COOH}, \mathrm{OSO}_{3} \mathrm{H}, \mathrm{OPO}_{2} \mathrm{H}_{2}, \mathrm{OPO}_{3} \mathrm{H}_{2}, \mathrm{NR}_{3}, \mathrm{CH}_{2} \mathrm{NR}_{3}{ }^{+}$ 
Scheme 4: $\quad$ Synthesis and homopolymerization of dimethylphosphonate-4-substituted- $\alpha, \beta, \beta-$ trifluorostyrene according to Stone et al. [89].

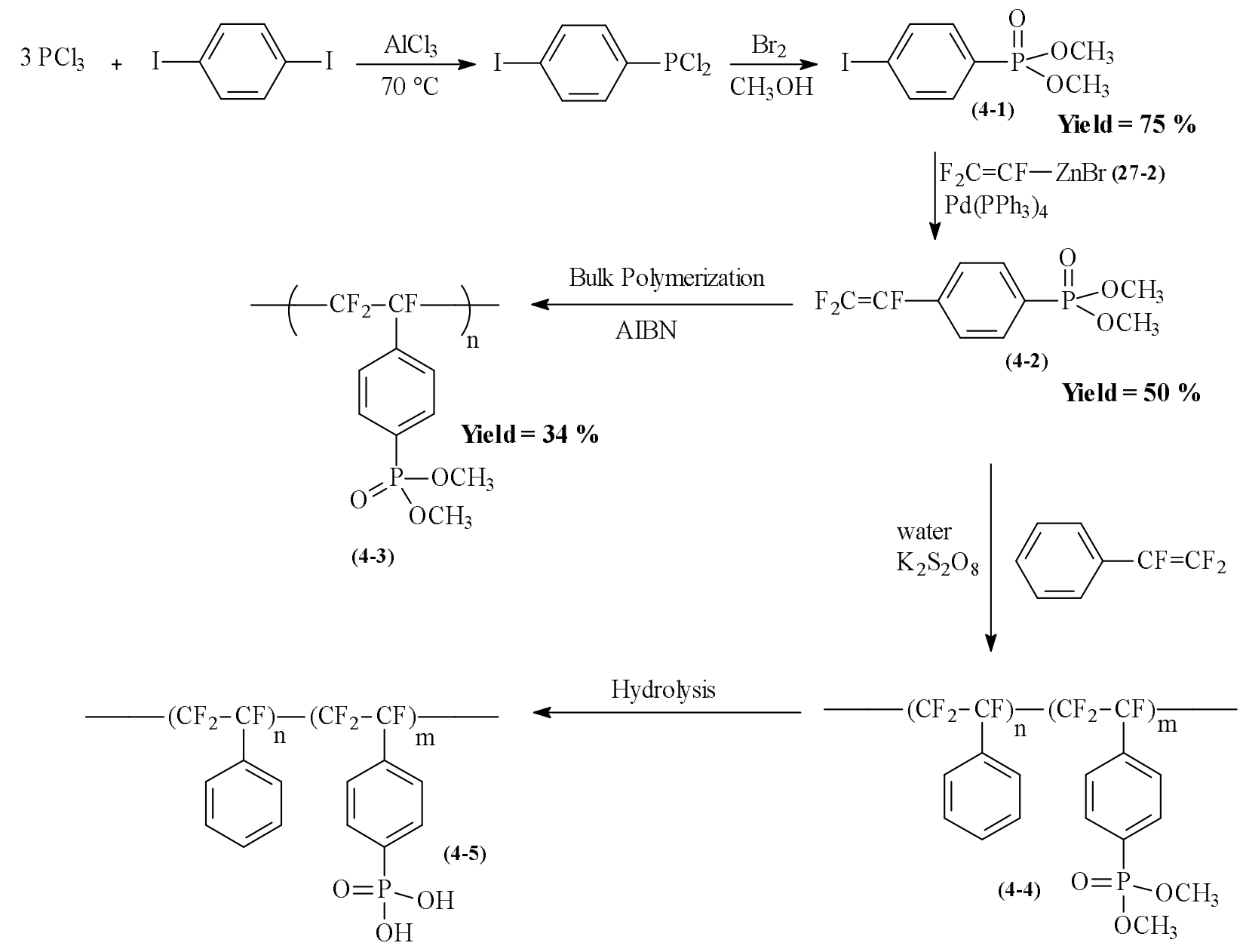


Scheme 5: Formation of aromatic perfluorocyclobutane (PFCB) $[95,99,120-125]$.

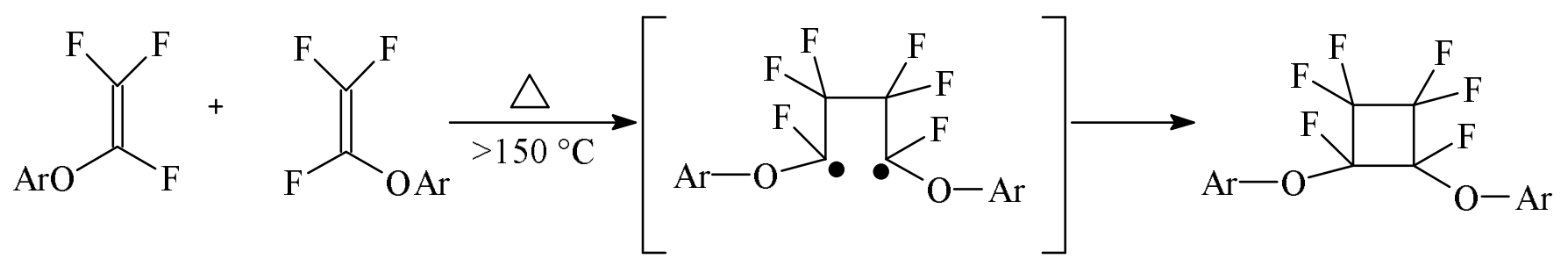


Scheme 6: General synthetic route of TFVOB preparation

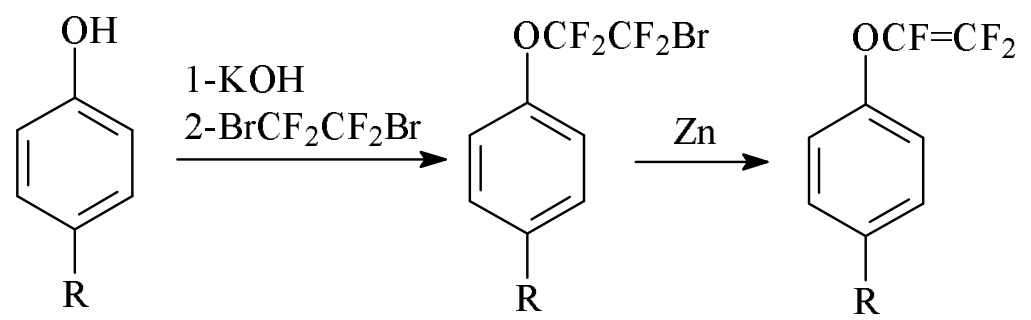


Scheme 7: Poly aryl vinyl ether synthesized by Smith et al. [117].<smiles>CC(C)C(=O)OC(F)=C(F)O[Al]OC(F)=C(F)F</smiles>

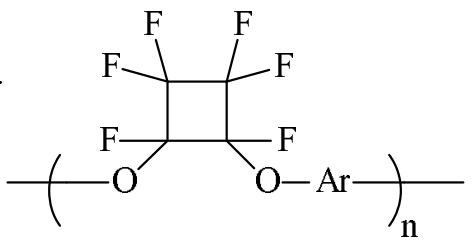<smiles>Cc1ccc(C(C)(c2ccc(C)cc2)c2ccc(OC(F)(F)F)cc2)cc1</smiles><smiles>Cc1ccc(-c2ccc(C)cc2)cc1</smiles><smiles>Cc1ccc(C2(c3ccc(C)cc3)c3ccccc3-c3ccccc32)cc1</smiles><smiles>CC(=Cc1ccc(C)cc1)c1ccc(C)cc1</smiles><smiles>Cc1ccc(C(c2ccc(C)cc2)(C(F)(F)F)C(F)(F)F)cc1</smiles> 
Scheme 8: Synthesis of new aromatic perfluorovinyl ether monomers containing phosphonic acid functionality [128].

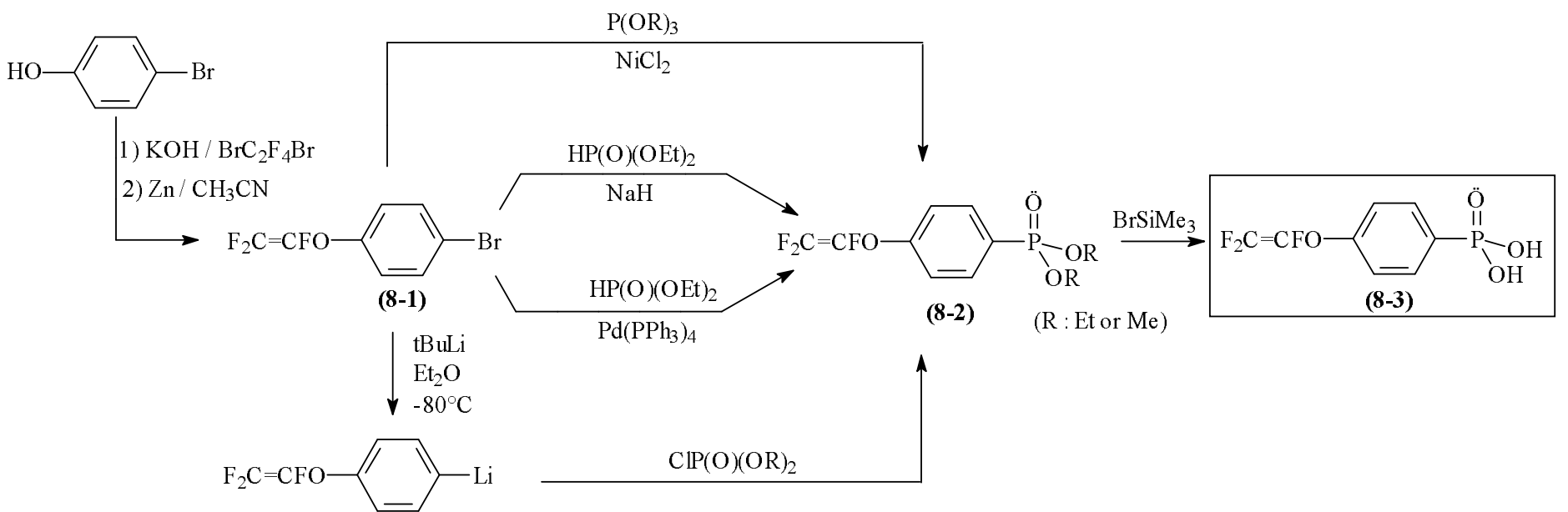


Scheme 9: Synthesis of aromatic perfluorovinyl ether monomers containing the sulfonamide and the sulfonic acid functionality according to Ford et al. [133]

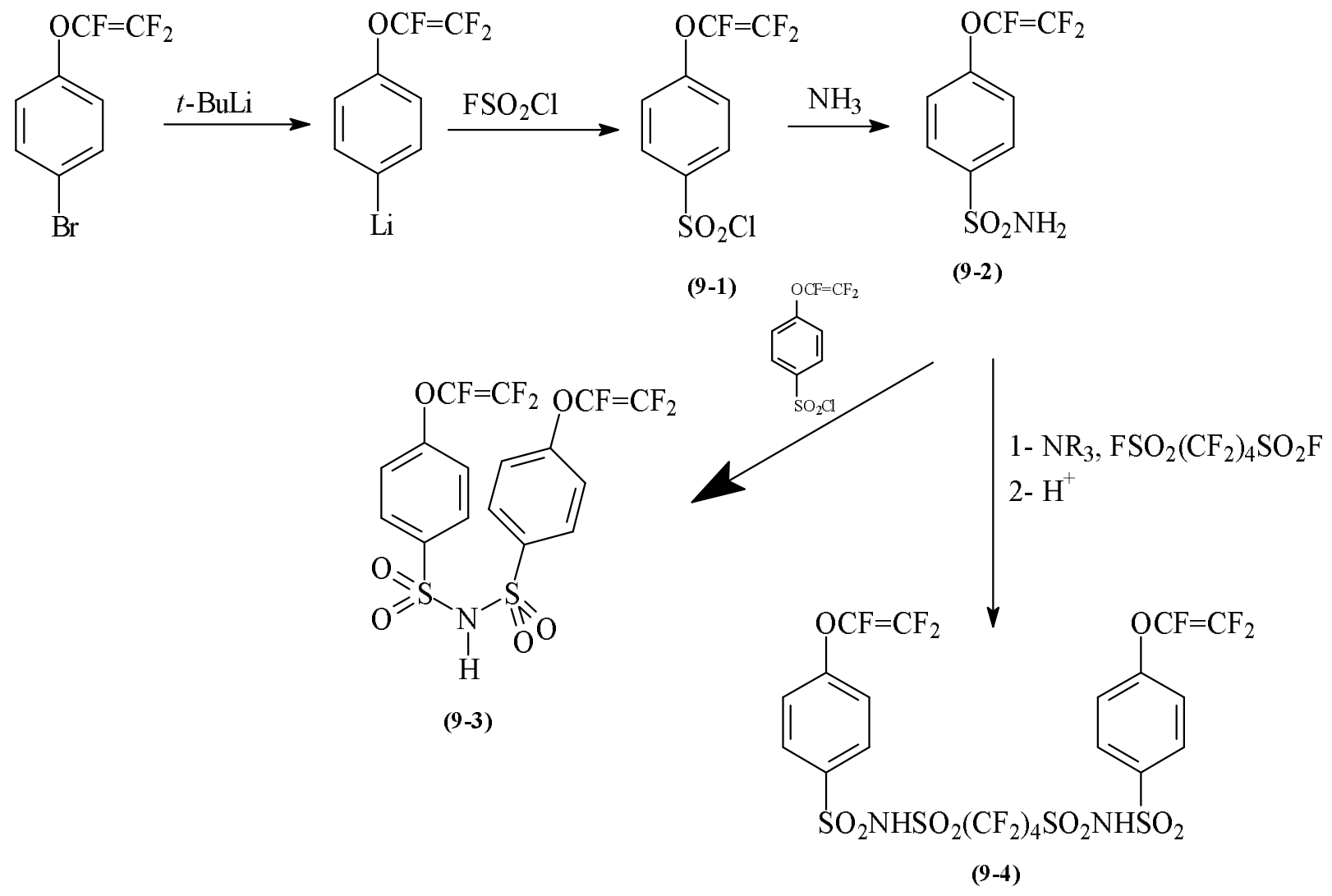


Scheme 10: Functionnalised polyarylene vinyl ethers according to 3M Innovative Properties company [104].
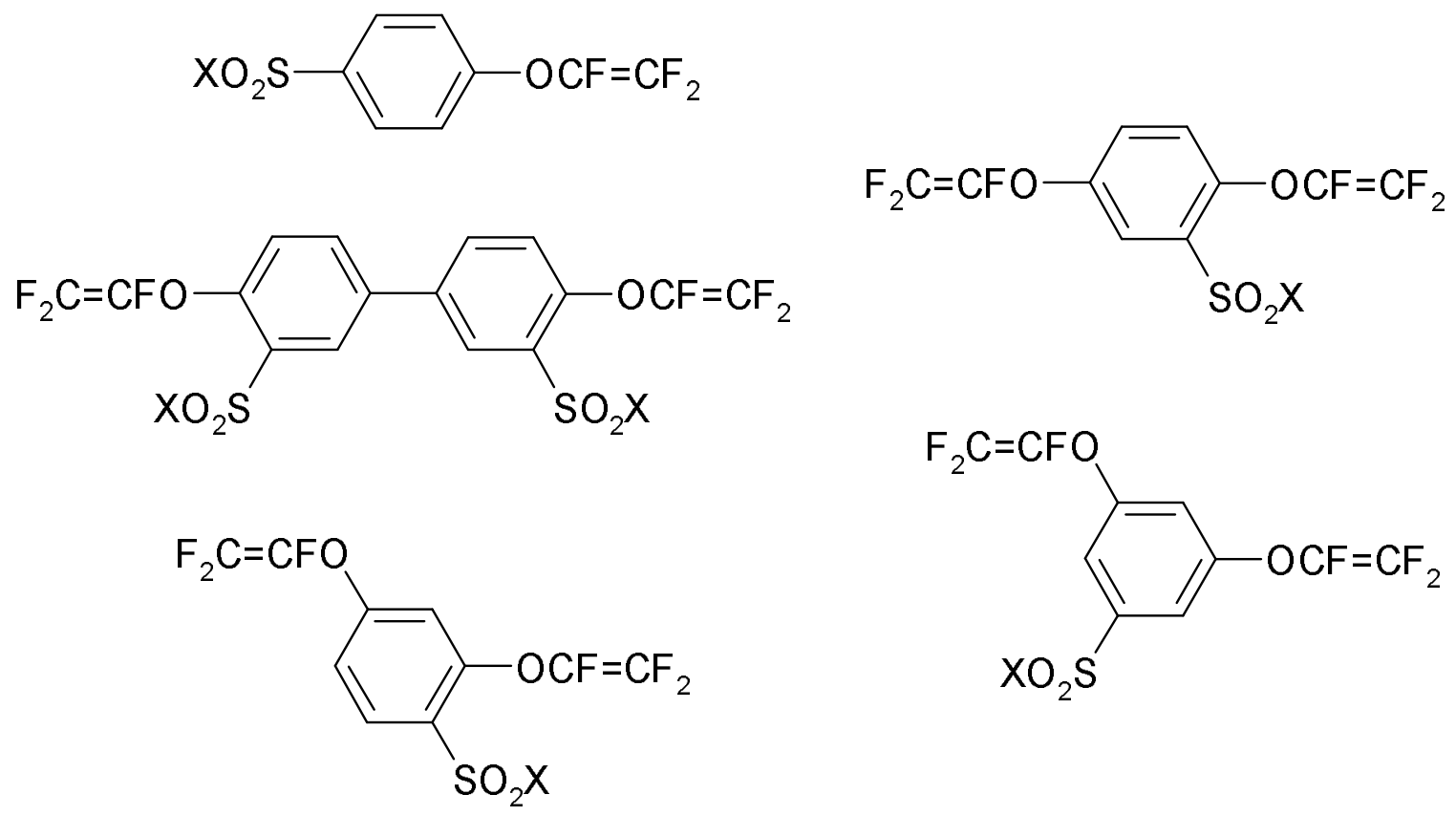
Scheme 11: Terpolymerization of $4-[(\alpha, \beta, \beta$-trifluorovinyl $) 0 x y]$ bromobenzene with Fluoroalkenes (VDF, HFP, PMVE and CTFE) [143].
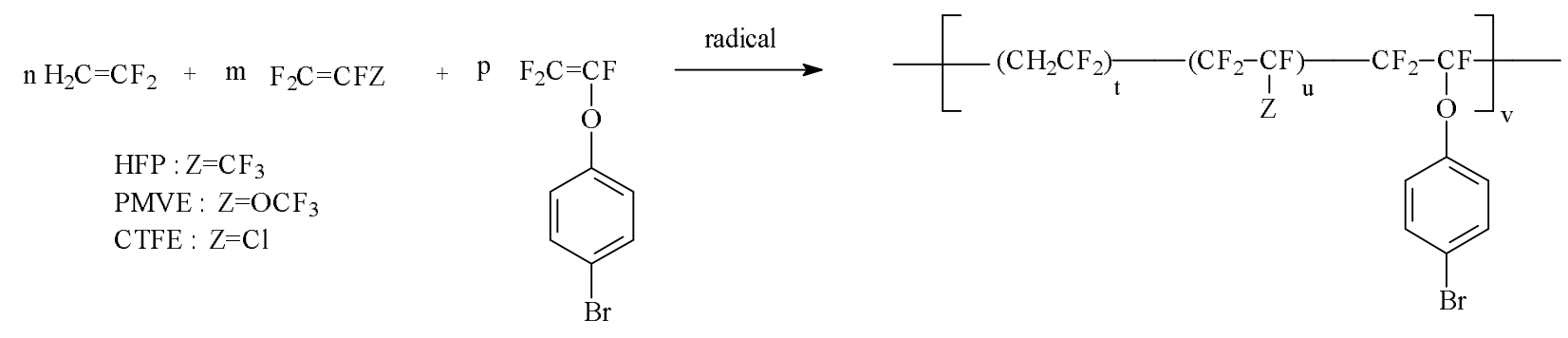
Scheme 12: Radical terpolymerization (I) of TFVOBSC with VDF and / or HFP and / or PMVE, and hydrolysis (II) of the correponding terpolymers [92,144].

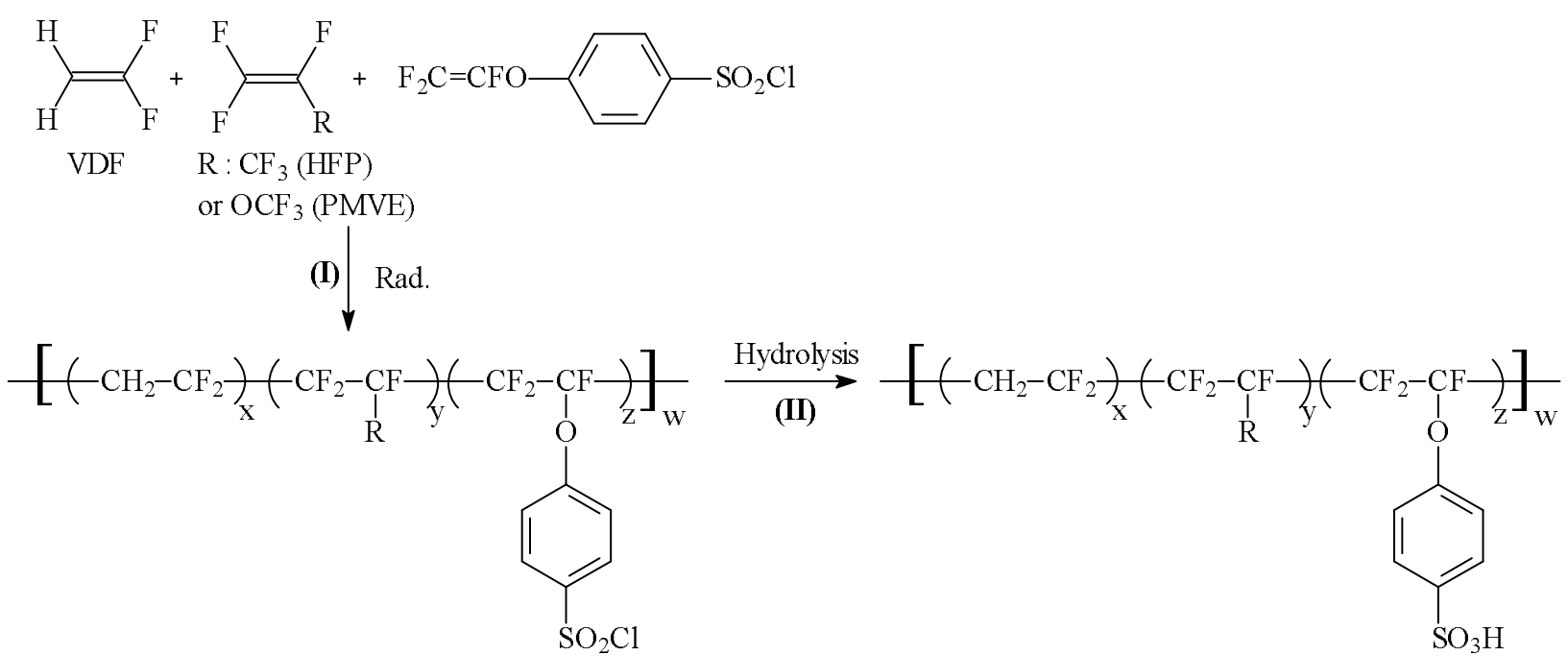

